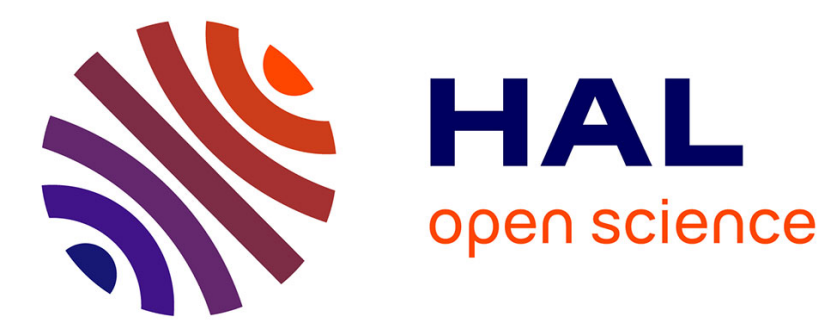

\title{
Effects of two sediment types on the fluorescence yield of two Hawaiian scleractinian corals \\ Gregory A. Piniak
}

\section{To cite this version:}

Gregory A. Piniak. Effects of two sediment types on the fluorescence yield of two Hawaiian scleractinian corals. Marine Environmental Research, 2007, 64 (4), pp.456. 10.1016/j.marenvres.2007.04.001 . hal-00562977

\section{HAL Id: hal-00562977 \\ https://hal.science/hal-00562977}

Submitted on 4 Feb 2011

HAL is a multi-disciplinary open access archive for the deposit and dissemination of scientific research documents, whether they are published or not. The documents may come from teaching and research institutions in France or abroad, or from public or private research centers.
L'archive ouverte pluridisciplinaire HAL, est destinée au dépôt et à la diffusion de documents scientifiques de niveau recherche, publiés ou non, émanant des établissements d'enseignement et de recherche français ou étrangers, des laboratoires publics ou privés. 


\section{Accepted Manuscript}

Effects of two sediment types on the fluorescence yield of two Hawaiian scleractinian corals

Gregory A. Piniak

PII:

S0141-1136(07)00056-6

DOI:

10.1016/j.marenvres.2007.04.001

Reference:

MERE 3115

To appear in:

Marine Environmental Research

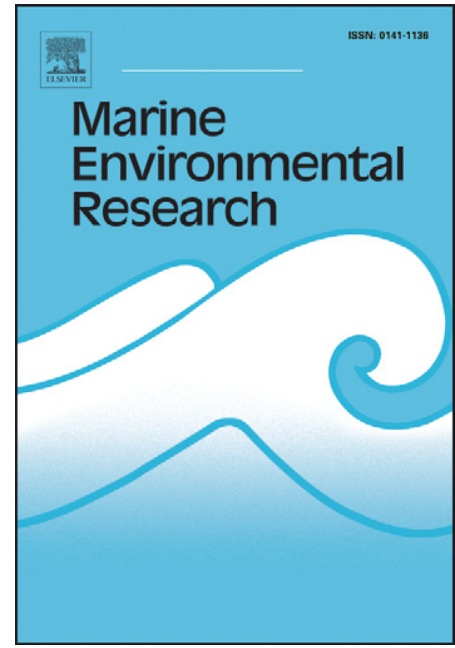

Received Date: $\quad 5$ June 2006

Revised Date: $\quad 2$ April 2007

Accepted Date: $\quad 2$ April 2007

Please cite this article as: Piniak, G.A., Effects of two sediment types on the fluorescence yield of two Hawaiian scleractinian corals, Marine Environmental Research (2007), doi: 10.1016/j.marenvres.2007.04.001

This is a PDF file of an unedited manuscript that has been accepted for publication. As a service to our customers we are providing this early version of the manuscript. The manuscript will undergo copyediting, typesetting, and review of the resulting proof before it is published in its final form. Please note that during the production process errors may be discovered which could affect the content, and all legal disclaimers that apply to the journal pertain. 


\title{
Effects of two sediment types on the fluorescence yield of two Hawaiian scleractinian corals
}

\author{
GREGORY A. PINIAK \\ USGS Pacific Science Center \\ 400 Natural Bridges Drive \\ Santa Cruz, CA 95060 USA \\ gpiniak@usgs.gov \\ fax (831) 427-4748 \\ phone (831) 427-4729
}

Current address: NOAA Center for Coastal Fisheries and Habitat Research, 101 Pivers Island

Road, Beaufort, NC 28516 USA. greg.piniak@ noaa.gov, fax 252-728-8784, phone 252-728-8732

Prepared for Marine Environmental Research, submitted June 2006

Keywords: Sediment, PAM, Porites lobata, Montipora capitata 
Abstract This study used non-invasive pulse amplitude modulated (PAM) fluorometry to measure the maximum fluorescence yield $\left(\mathrm{F}_{\mathrm{v}} / \mathrm{F}_{\mathrm{m}}\right)$ of two Hawaiian scleractinian coral species exposed to short-term sedimentation stress. Beach sand or harbor mud was applied to coral fragments in a flow-through aquarium system for 0-45 h, and changes in $\mathrm{F}_{\mathrm{v}} / \mathrm{F}_{\mathrm{m}}$ were measured as a function of sediment type and length of exposure. Corals were monitored for up to $90 \mathrm{~h}$ to document recovery after sediment removal. Sediment deposition significantly decreased $\mathrm{F}_{\mathrm{v}} / \mathrm{F}_{\mathrm{m}}$ in both species and was a function of sediment type and time. Corals that received sediment for $30 \mathrm{~h}$ or more had the greatest reduction in yield and exhibited little recovery over the course of the experiment. Harbor mud caused a greater reduction in Porites lobata yield than beach sand, whereas both sediment types had equally deleterious effects on Montipora capitata. Colony morphology and sediment type were important factors in determining yield reduction- $P$. lobata minimized damage from coarse sand grains by passive sediment rejection or accumulation in depressions in the skeleton, and fluorescence yield decreased most in corals exposed to sticky harbor mud or in colonies with flattened morphologies. Speciesspecific differences could not be tested due to differences in colony morphology and surface area. 
Sediment and fluorescence yield

\section{Introduction}

The effect of sedimentation on corals depends on colony characteristics, sediment type and environmental conditions (see reviews by Rogers, 1990; Fabricius, 2005). Many corals can actively remove sediment deposited directly on the surface of the colony (Bak and Elgershuizen, 1976; Lasker, 1980; Dallmeyer et al., 1982; Stafford-Smith and Ormond, 1992; Stafford-Smith; 1993). In the short term, sediment deposition decreases photosynthetic efficiency (Philipp and Fabricius, 2003; Weber et al., 2006), increases coral respiration, and decreases photosynthesis/respiration ratios (Dallmeyer et al., 1982; Riegl and Branch, 1995; Telesnicki and Goldberg, 1995; Te, 2001; Anthony and Connolly, 2004). When the sediment is not removed, corals may bleach and/or die (Rogers, 1983; Rice, 1984; Gilmour, 2002).

Sedimentation is a natural part of coral reef dynamics, but changes in land-use patterns can alter the quantity and quality of sediment in the nearshore coastal ocean. In Hawaii, sedimentation may pose a particular threat in populated areas like Maui and Oahu (Gulko et al., 2000), or in areas of low wave energy. Beach and nearshore seafloor sediment in Hawaii is predominantly marine carbonates, while the small size fractions (silts and clays) are often terrigenous in origin (Harney et al., 2000; Calhoun and Field, 2002; Storlazzi et al., 2004; Bothner et al., 2006). Terrestrial sediment is likely to be the most dangerous to reef corals, since sediment runoff from urban and agricultural areas often contains harmful organic compounds, heavy metals, or nutrients (Glynn et al., 1984; Glynn et al., 1989; Bastidas et al., 1999; Jokiel et al., 2004; see also review by Fabricius, 2005). Grain size, organic content, and nutrient-related properties are primary 
factors in determining sedimentation stress in corals (Weber et al., 2006). Nutrient-rich terrestrial sediment can be biologically aggregated into marine snow, which can be detrimental or lethal to reef organisms after just a few hours' exposure (Fabricius and Wolanski, 2000).

Pulse amplitude modulated (PAM) fluorometry is a sensitive measure of sublethal stress in photosynthetic organisms, and a decrease in maximum fluorescence yield $\left(\mathrm{F}_{\mathrm{v}} / \mathrm{F}_{\mathrm{m}}\right)$ has been used to document coral stress from herbicides (Raberg et al., 2003; Jones et al., 2003; Jones and Kerswell, 2003), and abnormal temperatures (Jones et al., 1998; Warner et al., 1999; Ralph et al., 2001; Saxby et al., 2003). Previous investigations of short-term sediment deposition on corals have demonstrated that fluorescence yield is a function of sediment amount and the duration of exposure (Philipp and Fabricius 2003), and that stress levels are highly correlated with nutrient/organic content (Weber et al., 2006). The present study generalizes these findings, using a DIVING-PAM to document decreases in $\mathrm{F}_{\mathrm{v}} / \mathrm{F}_{\mathrm{m}}$ caused by short-term (0-45 h) sedimentation exposure for Montipora capitata and Porites lobata, two of the most prevalent reef coral species in Hawaii (Jokiel et al., 2004; Brown, 2004).

\section{Materials and Methods}

\subsection{Sediment characterization}

Sediment was collected from two sites in Maui, Hawaii: Maalaea Harbor $\left(20^{\circ} 47.539^{\prime} \mathrm{N}, 1^{\circ} 6^{\circ} 30.626^{\prime} \mathrm{W}\right.$, depth $\left.=3 \mathrm{~m}\right)$ and Sugar Beach $\left(20^{\circ} 47.798^{\prime} \mathrm{N}\right.$, $156^{\circ} 30.074^{\prime} \mathrm{W}$, depth $<0.1 \mathrm{~m}$ ). Grain size analyses (Table 1) were conducted by methods standardized by the Western Coastal and Marine Geology team of the United States Geological Survey (modified from Carver, 1971 and Folk, 1974). Sediment 
particles 63-2000 $\mathrm{m}$ were separated using 2-m settling tubes for grain size analysis (modified from Theide et al., 1976). Carbon and carbonate analyses were conducted with UIC Coulometrics systems CM 150 and CM 5200. The sediment at Sugar Beach was predominantly carbonate sand, while the sediment at Maalaea Harbor was a mixture of shell hash, sand, and mud, and had low carbonate content (Table 1).

X-ray diffraction mineralogy indicated the beach sand was primarily biogenic carbonate; the harbor mud contained more silicates (pyroxenes, chlorites and/or kaolinite) and iron oxide than the beach sand. The chemical composition of the sediment was determined by commercially available X-ray fluorescence and inductively coupled plasma mass spectrometry techniques; the harbor mud contained higher concentrations of trace and heavy metals than the beach sand (Table 2).

\subsection{Experimental design}

Colonies of Porites lobata and Montipora capitata (20-40 cm diameter) were collected $\sim 1.8 \mathrm{~km}$ offshore of Sugar Beach, Maui $\left(20^{\circ} 46.459^{\prime} \mathrm{N}, 156^{\circ} 28.869^{\prime} \mathrm{W}\right.$, depth = 12-15 m), and returned to the laboratory at the Maui Ocean Center. Both species also inhabit Maalaea Harbor, but P. lobata colonies in the harbor were generally too large for efficient collection so both species were collected from outside the harbor. Colonies were broken into fragments using a hammer and chisel and the underside trimmed such that the colony surface lay as flat as possible. Small Floy Tags® (Seattle, WA) were used to label each colony by embedding the tag in a small dab of Splash Zone® epoxy (Carboline Company, St. Louis, MO) attached to bare skeletal material. Coral fragments were randomly assigned positions within an outdoor, open, flow-through tank $(5.4 \mathrm{~L} / \mathrm{min}$, 
$27-28^{\circ} \mathrm{C}, 35 \mathrm{ppt}$ ) and allowed to recover for 2 days. Corals were elevated above the bottom of the tank by placing them directly on a plastic grid supported by cinder blocks, so that the water depth above the corals was $0.4 \mathrm{~m}$. The tank was covered with three layers of neutral-density screen so that light reaching the corals was $\sim 22 \%$ of ambient (13 h:11 h light:dark cycle). Light levels in the tank during the experiment were measured at 15-min intervals with a LICOR LI-192SA underwater quantum sensor and a LICOR LI1400 data logger. Differences in colony size and shape resulted in an unequal number of fragments from each donor colony, so coral fragments were not blocked according to genetics. Instead corals were randomly assigned to each experimental treatment (beach sand or harbor mud, $\mathrm{n}=12$ per species per treatment), with three additional fragments of each species kept as controls.

The night the experiment was initiated, each fragment was transferred to a small flow-through chamber $(0.65 \mathrm{~L} / \mathrm{min})$ for baseline measurements with a pulse-amplitude modulated fluorometer (DIVING-PAM, Walz GmbH, Germany). A universal sample holder (DIVING-USH) was used to fix the fiberoptic probe $3 \mathrm{~mm}$ from and perpendicular to the surface of a coral. The PAM was calibrated so that the settings (gain $=2$, damp $=$ 2 , measuring intensity $=7$ ) produced initial fluorescence measurements $\left(F_{o}\right)$ of $\sim 300-500$ units when a weak pulsed blue light was applied to dark-adapted corals of both species. Maximum fluorescence $\left(\mathrm{F}_{\mathrm{m}}\right)$ was measured using a saturating light pulse $(0.8 \mathrm{~s},>1000$ $\mu$ mol photons $\left.\mathrm{m}^{-2} \mathrm{~s}^{-1}\right)$, and the change in fluorescence $\left(\mathrm{F}_{\mathrm{v}}=\mathrm{F}_{\mathrm{m}}-\mathrm{F}_{\mathrm{o}}\right)$ was used to calculate maximum quantum yield $\left(\mathrm{F}_{\mathrm{v}} / \mathrm{F}_{\mathrm{m}}\right)$ for dark-adapted corals (Genty et al., 1989). After 15 yield measurements were made across the entire coral surface, the fragment was returned to its place in the original holding tank. 
After baseline PAM measurements, water flow to the main tank was turned off and $125 \mathrm{ml}$ of sediment slurry (average \pm SD $248 \pm 4 \mathrm{~g}$ sand, $206 \pm 3 \mathrm{~g}$ mud) was spread evenly over the surface of each experimental fragment. No sediment was applied to the control corals. The sediment was allowed to settle for $3 \mathrm{~h}$ before restarting water flow in the tank. At 6, 21, 30, and $45 \mathrm{~h}$ after sediment application, sediment was removed from three corals of each species and retained for weighing. At each time point, fluorometry measurements were taken for all corals that had been cleaned of sediment; all corals were sampled after $45 \mathrm{~h}$. Additional PAM measurements were taken 54, 69, and $93 \mathrm{~h}$ after sediment application to document recovery from sediment stress. In order to conduct all measurements in darkness, all sampling periods were scheduled either $2 \mathrm{~h}$ before sunrise $(6,30,54 \mathrm{~h})$, or $1 \mathrm{~h}$ after darkness $(21,45,69,93 \mathrm{~h})$. At the end of the experiment, the sediment collected from each coral was filtered and dried at $50^{\circ} \mathrm{C}$ to a constant weight. At the conclusion of the experiment the surface area of each coral was measured with the tin foil method (Marsh, 1970), and the 2-dimensional planar area was determined by image analysis in CPCe (Kohler and Gill, 2006).

\subsection{Statistical analysis}

Statistical analysis was conducted using SYSTAT 8.0 (SPSS, 1998). Data were

tested for homoscedasticity using the Scheffe-Box test, and normality assumptions were tested using a Kolmogorov-Smirnoff test for goodness of fit (Sokal and Rohlf, 1995). Data that met these assumptions were analyzed with ANOVAs. The relationship between fluorescence yield and sediment dose was examined using a series of linear regressions. When fluorescence yields did not meet parametric assumptions, they were 
normalized by the theoretical maximum yield ( 0.7 for corals), and acrsin-square root transformed as much as twice (Philipp and Fabricius, 2003). Data that failed to meet assumptions after transformations were analyzed using nonparametric statistics. When appropriate, multiple regression slopes were tested for homogeneity as an analysis of covariance (Sokal and Rohlf, 1995).

\section{Results}

\subsection{Sediment duration vs. fluorescence yield}

Fluorescence yield $\left(\mathrm{F}_{\mathrm{v}} / \mathrm{F}_{\mathrm{m}}\right)$ for corals not exposed to sediment ranged from 0.57 0.69 for Montipora capitata and 0.55-0.64 for Porites lobata, and were constant over the duration of the experiment (Fig. 1). A nonparametric two-way ANOVA (Scheirer-RayHare extension of Kruskal-Wallis; Sokal and Rohlf, 1995) of the entire dataset found significant effects of sediment, time, and sediment*time interaction on $F_{v} / F_{m}$ for both species (Fig. 1, Table 3). Short-term sedimentation $(<30 \mathrm{~h})$ had relatively little effect on coral yields, although yields declined significantly as the duration of the stress increased (Fig. 1). As sediment application typically reduced fluorescence yield, data were reanalyzed with controls excluded (Weber et al., 2006) so that effects of sediment type could be tested more directly. Harbor mud caused a greater reduction in P. lobata $\mathrm{F}_{\mathrm{v}} / \mathrm{F}_{\mathrm{m}}$ than beach sand (Table 4). In contrast, both sediment types had equally deleterious effects in $M$. capitata, and duration of the stress was the significant factor decreasing yields (Table 4). 
Sediment and fluorescence yield

\subsection{Sediment dose and exposure vs. fluorescence yield}

There was no significant difference in planar area for fragments of the two species (M. capitata $76 \pm 6 \mathrm{~cm}^{2}, P$. lobata $80 \pm 5 \mathrm{~cm}^{2}$; average $\left.\pm 1 \mathrm{SE}, \mathrm{F}_{1,48}=0.27, \mathrm{P}=0.61\right)$, but total surface area was significantly different $\left(M\right.$. capitata $96 \pm 7 \mathrm{~cm}^{2}, P$. lobata $145 \pm 8$ $\left.\mathrm{cm}^{2}, \mathrm{~F}_{1,52}=20.71, \mathrm{P}<0.001\right)$. Sediment doses were applied volumetrically $(125 \mathrm{ml}$ sediment $\operatorname{coral}^{-1}$ ). The average sediment dose $\pm 1 \mathrm{SE}$ recovered from the coral fragments was $301 \pm 235 \mathrm{mg} \mathrm{cm}^{-2}$ for $M$. capitata with mud, $509 \pm 199$ for $M$. capitata with sand, $137 \pm 83$ for $P$. lobata with mud, and $68 \pm 38$ for $P$. lobata with sand. The amount of sediment recovered did not change over time for any of the treatments, suggesting that sediment removal by the live colonies was minimal after the initial $6 \mathrm{~h}$ of exposure. Regressions were conducted for each dose duration $(6,21,30,45 \mathrm{~h})$ within a given species/sediment treatment (Fig. 2). The slopes of the regressions were all negative, and differed with time for all species/sediment combinations: $M$. capitata with mud $\left(\mathrm{F}_{3,16}=\right.$ 3.52, $\mathrm{P}<0.05)$, M. capitata with sand $\left(\mathrm{F}_{3,16}=9.68, \mathrm{P}<0.001\right)$, P. lobata with mud $\left(\mathrm{F}_{3,16}\right.$ $=10.81, \mathrm{P}<0.001)$, and P. lobata with sand $\left(\mathrm{F}_{3,16}=48.27, \mathrm{P}<0.001\right)$. Generally, the longer time periods had slopes that were more negative.

When the effects of sediment dose and time are collapsed into a single sediment exposure factor $\left(\mathrm{g} \mathrm{h} \mathrm{cm}^{-2}\right.$, sensu Philipp and Fabricius, 2003) for regression, all four species/treatment combinations (Fig. 3) showed a strong linear negative effect of exposure on fluorescence yield $\left(M\right.$. capitata mud $\mathrm{F}_{1,10}=45.71, \mathrm{P}<0.001 ;$ M. capitata sand $\mathrm{F}_{1,10}=17.35, \mathrm{P}<0.001 ;$ P. lobata mud $\mathrm{F}_{1,10}=31.64, \mathrm{P}<0.001 ;$ P. lobata sand $\mathrm{F}_{1,10}$ $=6.24, \mathrm{P}<0.025)$. Linear models also explained a greater proportion of the variability 
for mud exposure than sand, especially for P. lobata. Slopes for the mud regressions were twice as steep as those for sand, but this difference was not statistically significant for either species $\left(M\right.$. capitata $\mathrm{F}_{1,20}=1.11, \mathrm{P}>0.25 ;$ P. lobata $\left.\mathrm{F}_{1,20}=1.38, \mathrm{P}>0.25\right)$.

\subsection{Recovery from sediment stress}

Corals were montiored for at least $48 \mathrm{~h}$ after sediment removal to evaluate prospects for short-term recovery (Fig. 4). Corals exposed to sediment for $<30 \mathrm{~h}$ had depressed yields and either recovered quickly (P. lobata) or maintained slightly depressed yields with little recovery over the length of the experiment (M. capitata). Corals of both species that endured sediment stress for $45 \mathrm{~h}$ had very low yields, but began to recover within $48 \mathrm{~h}$ of sediment removal. Yields in P. lobata exposed to sand for $45 \mathrm{~h}$ were similar to those of control corals, as relatively little sand remained on the coral surface at that time. However, when corals were unable to remove sediment from the surface, tissue discoloration and necrosis occurred (Fig. 5), which further inhibited recovery.

\section{Discussion}

The present study evaluated the effect of short-term sediment deposition on two common Hawaiian scleractinian corals, Montipora capitata and Porites lobata. Fluorescence yield $\left(\mathrm{F}_{\mathrm{v}} / \mathrm{F}_{\mathrm{m}}\right)$ was significantly depressed in both P. lobata and M. capitata as a result of sediment deposition. The decrease was a function of sediment type and time, and the relationship between fluorescence yield and sediment exposure $\left(\mathrm{g} \mathrm{h} \mathrm{cm}^{-2}\right)$ was linear for both species. These results are consistent with similar studies of the Australian coral Montipora peltiformis (Philipp and Fabricius, 2003). In addition, the 
present study found that deposition of terrigenous sediment (harbor mud) had a greater negative effect on fluorescence yield than carbonate sand in $P$. lobata, but not $M$. capitata. Weber et al. (2006) also found a significant effect of sediment type on fluorescence yield, as sandy sediment was far less stressful than silt for M. peltiformis.

Despite tuning the PAM so that the initial fluorescence $\left(\mathrm{F}_{\mathrm{o}}\right)$ values were in an appropriate range (300-500 units), the fluorescence yields in the controls were lower than expected. Theoretical maximum yields for corals are $\sim 0.7$, but in the present study the average yield for controls was 0.62 for $M$. capitata and 0.59 for P. lobata. It is possible that yields were lower because the recovery period ( 2 d) following fragmentation was insufficient. As corals require 5-10 days for photoacclimation (Anthony and HoeghGuldberg, 2003), it is also possible that lower yields were a result of photoacclimation to light conditions in the flow-through tank. A typical average light extinction coefficient for clear inshore coastal Hawaiian waters is -0.25 (SOEST, 2004); the $78 \%$ reduction in light by the shade cloth in this study would correspond to a virtual depth of only $\sim 6 \mathrm{~m}$, while the corals were originally collected from $12-15 \mathrm{~m}$. Thus the zooxanthellae in the tank may have experienced a greater amount of PAR than at the collection site, although the yields of control corals did not appear to increase over the course of the experiment.

\subsection{Species responses}

Previous studies of these two species suggested that $M$. capitata would be the more sediment-tolerant of the two species. Although they often coexist in the field, $M$. capitata predominates inshore turbid reef environments (Te, 2001; Dollar and Grigg, 2004), while massive $P$. lobata colonies are characteristic of sites with moderate wave energy (Jokiel et al., 2004). In addition, P. lobata is rapidly damaged by sediment 
Sediment and fluorescence yield

deposition, while $M$. capitata is physiologically resistant to sedimentation (Hodgson, 1989). These two genera typically have poor active sediment rejection abilities (StaffordSmith and Ormond, 1992), though sediment rejection efficiency and sediment tolerance are not directly related (Stafford-Smith, 1993).

However, the responses of the two coral species could not be statistically compared in this study because of an experimental artifact related to colony morphology. The parent colonies were initially subdivided with a hammer and chisel, and the resulting experimental fragments were selected to be similar in planar area. M. capitata fragments tended to be relatively flat, while $P$. lobata were more topographically complex, so when surface area was measured at the end of the experiment there was a significant difference in coral size between treatments (however there was no difference within treatments for either species). As a constant volume of sediment was initially applied (125 $\mathrm{ml}$ of sediment per coral), the difference in colony size resulted in a significantly higher sediment exposure for $M$. capitata than $P$. lobata $\left(\mathrm{F}_{3,44}=9.16, \mathrm{P}<0.001\right)$. There was no significant difference between the amount of sand or mud applied within a species $(M$. capitata average $\pm \mathrm{SE} 2.2 \pm 0.2 \mathrm{~g} \mathrm{~cm}^{-2}$ mud or $2.8 \pm 0.3 \mathrm{~g} \mathrm{~cm}^{-2}$ sand, $\mathrm{F}_{1,22}=3.97, \mathrm{P}<$ $0.05 ; P$. lobata average $\pm \mathrm{SE} 1.5 \pm 0.1 \mathrm{~g} \mathrm{~cm}^{-2}$ mud or $1.6 \pm 0.2 \mathrm{~g} \mathrm{~cm}^{-2}$ sand, $\mathrm{F}_{1,22}=0.07, \mathrm{P}$ $>0.75$ ), so the comparison of sediment types within a given species remains valid.

\subsection{Response to sediment types}

Corals that clear sediment from their surface generally do so within hours or a few days (Lasker, 1980; Stafford-Smith, 1993), but for three of the species/sediment type treatments studied here, sediment rejection was incomplete after $45 \mathrm{~h}$. Heavy, coarse grains are easily (and often passively) removed from vertical or inclined surfaces 
(Stafford-Smith and Ormond, 1992). This mechanism likely allowed P. lobata to minimize the effects of beach sand, which was shed from the colony surface or concentrated in depressions of the coral's mounding morphology. However, fine sediment requires active rejection, even from vertical surfaces (Stafford-Smith and Ormond, 1992), and in this study, P. lobata was less effective at removing harbor mud than sand from the colony surface. On horizontal surfaces, fine sediment is actively rejected more easily than coarse grains (Stafford-Smith, 1993), but M. capitata was unable to reject either the beach sand or harbor mud in this experiment.

While the inefficiency of mud removal in P. lobata and M. capitata could be a function of grain size, it is possible that the chemical composition of the sediment inhibited removal. Carbonates are more easily removed than terrestrial sediment of similar grain size (Weber et al., 2006). Terrestrial sediment can become sticky with mucus, forming flocs of marine snow that are detrimental to reef organisms (Fabricius and Wolanski, 2000). Bak and Elgershuizen (1976) found no difference in the rejection of oiled and clean sediment, but physical contact with oiled sediment was less harmful than direct toxic effects of the oils themselves. In contrast, Thompson and Bright (1977) found that drilling mud was more difficult for corals to remove than clean sediment. However, the sediment does not have to directly contact the coral for sediment composition to matter-terrigenous silt reduced net photosynthesis in Montipora capitata by $28 \%$, but an equal concentration of carbonate silt reduced photosynthesis by only $10 \%$ (Te, 2001).

Philipp and Fabricius (2003) identified a sediment damage threshold of 24-36 h, beyond which irreversible bleaching and tissue damage occurred. The threshold in the 
present study was similar $-P$. lobata and $M$. capitata exposed to sediment for $<30 \mathrm{~h}$ experienced a reduction in yield, but little tissue discoloration occurred. Recovery in these cases was often fairly rapid; at the very least, no additional damage was incurred after sediment removal (Fig. 4). Sediment applied for 30-45 h caused a greater decrease in yield, and extensive tissue damage (Fig. 5). In those instances, fluorescence yield recovered only slightly by the end of the experiment (Fig. 4); any improvement was due to improved yield in bleached areas, while areas that were necrotic turned anoxic, shed tissue, and had zero yield.

\subsection{Implications for field studies}

Reefs not subject to human stress receive $1-10 \mathrm{mg} \mathrm{cm}^{-2} \mathrm{~d}^{-1}$ of sediment deposition (Rogers, 1990), but in heavily populated high-island systems like Hawaii, sediment levels may be considerably higher. The average sediment loads applied in this study were 1.5$2.8 \mathrm{~g} \mathrm{~cm}^{-2}$, but are not incompatible with sediment trap collection data in Hawaiian waters. For example, sediment traps on the south Molokai forereef collected an average of $50 \mathrm{mg} \mathrm{cm}^{-2} \mathrm{~d}^{-1}$ in $2001-2002$ but reached up to $1800 \mathrm{mg} \mathrm{cm}^{-2} \mathrm{~d}^{-1}$ during storm events (Bothner et al., 2006). Severe delivery events can persist over time-a single winter storm runoff event produced sediment that persisted in Honolua Bay, Maui, for several months, until storm waves eventually flushed the terrigenous sediment from the system (Dollar and Grigg, 2004).

The present study used a wide range of grain sizes (Table 1) in a laboratory tank to simulate an acute sedimentation event. This necessarily assumes that similar types of material can be delivered to corals in the field, as the possible effects of sedimentation will depend on sediment availability and especially on the physical forces driving the 
system. Sedimentation in the field is highest in sheltered waters and deeper reef slopes (Fabricius, 2005). In shallow Maalaea Harbor, sediment traps near the wave-exposed harbor mouth (where $P$. lobata predominates) collect primarily sand, while traps further into the harbor with less wave energy (where M. capitata and Pocillopora damicornis are more abundant) collect primarily silt (Piniak and Brown, 2007). In more exposed areas such as the reef flat in Molokai, Hawaii, trade wind-generated waves resuspend fine terrigenous sediment on a daily basis (Storlazzi et al., 2004; Ogston et al., 2004), and sediment traps on the Molokai reef flat collect predominantly silts and clays (Bothner et al., 2006). Constant resuspension and deposition means that a single sediment pulse could affect corals repeatedly, until it is flushed from the system. In deeper waters with less wave energy, sediment can accumulate until flushed by cyclones (Wolanski et al., 2005), but wave energy in some areas of Hawaii is sufficient to resuspend gravel-sized particles at depths of $10 \mathrm{~m}$ (Bothner et al., 2006). These processes can also move a substantial amount of sediment through the system, even in areas where sediment does not accumulate on the seafloor.

In her seminal review paper on coral reefs and sedimentation, Rogers (1990) noted that scientists are "unable to rigorously predict the responses of coral reefs and reef organisms to excessive sedimentation." Rogers specifically identified a need for threshold levels for lethal effects. The results of this study and others (Philipp and Fabricius, 2003; Weber et al., 2006) seem to indicate a deposition threshold of 30-36 h, as corals buried for that long did not recover in the short term (up to 4 days). There are two caveats to this threshold, however. First, the linear nature of the exposure graphs (Fig. 3; Fig. 4B in Philipp and Fabricius, 2003) indicates that the amount of sediment 
deposited is just as important as the duration. Second, recovery may depend on the property measured. For example, visual observations suggest that corals do sometimes recover from severe sediment burial in the field, but it generally occurs on a time scale of weeks to months (Wesseling et al., 1999). In contrast, fluorescence may indicate photodamage even if the tissue appears visually healthy. Fluorescence yield may or may not return to baseline after short-term damage (present study; Philipp and Fabricius, 2003; Weber et al. 2006), and reduced yields may persist for up to a year following bleaching events (Lombardi et al., 2000). While decreased fluorescence yield is a common stress response, few studies have examined the energetic consequences of such changes. Daily energetic costs of natural photoinhibition (i.e., reduced yield due to light stress) are negligible but can have adverse effects in the long term (Hoogenboom et al., 2006). Sedimentation stress has the additional danger of tissue loss or necrosis due to smothering.

Rogers (1990) also recommended that studies compare the effects of terrigenous and carbonate sediment. The two sediment types in the present study were extensively characterized in terms of sediment size and trace metal content (Tables 1-2); in addition, nutrient-related properties (total organic carbon, nitrogen, phosphorus, chlorophyll) can be the primary driver of sedimentation stress (Weber et al. 2006). Even when the sediment is comprehensively characterized, it is difficult to determine the specific properties of the sediment that decrease fluorescence yield. Possible mechanisms include physical smothering, chemical effects, anoxia, and indirect effects from any microbial assemblages associated with the sediment, or some combination of the above. Physical smothering could have reduced available light or gas exchange for photosynthesis (or 
both). Microbial activity associated with certain sediment types can also be detrimental to corals (Hodgson, 1990), but this effect has not been extensively studied. Chemical effects could be due to organic compounds or heavy metals in the sediment. Maalaea Harbor mud generally had higher amounts of trace metals than sand from Sugar Beach (Table 2). The Sugar Beach sand had relatively low trace metal content, similar to that of Molokai forereef sediment (Bothner et al., 2006) and sediment used by Weber et al. (2006) to study sediment stress on corals. The sediment was much lower in lead and cadmium than reef sediment in Central America (Guzman and Jimenez, 1992; Bastidas et al., 1999). The Maalaea mud had elevated chromium, copper, nickel, and vanadium; chromium and nickel levels exceeded the Probable Effects Level (PEL) established for marine sediment (MacDonald et al., 1996). Weber et al. (2006) found stress levels to be unrelated to the low concentrations of the few heavy metals measured in their study, but toxicity thresholds have not been established for most of these contaminants and specific effects on corals remain to be investigated.

\section{Conclusions and future concerns}

Effective management of sediment impacts will require a greater understanding of the specific causes of coral damage, and thresholds for that damage to occur. PAM fluorometry has good potential for such applications, as fluorescence yield is a sensitive, non-invasive indicator of sublethal stress. However there are several caveats to consider in designing future experiments. The measurements are physically simple but can be executed using a variety of methods. Photosynthetic efficiency varies spatially over the surface of the colony (Ralph et al., 2002), so measurement location can be important. Yields also vary over multiple time scales and with a number of environmental 
parameters, so context is of critical importance when interpreting fluorescence yields, especially in the field (Fitt et al., 2001) and with complex stressors like sediment (Weber et al., 2006). The site, environmental conditions, and stress characteristics should be described as completely as possible. Finally, PAM studies may be most effective when paired with additional response variables, since yield reduction may not always have an energetic consequence (Hoogenboom et al., 2006).

Acknowledgements This study was funded by a United States Geological Survey Mendenhall Postdoctoral Research Fellowship. These experiments complied with the current laws of the state of Hawaii, under permit by the Hawaii Department of Aquatic Resources. The Maui Ocean Center provided invaluable logistic support and field assistance. The manuscript was improved by comments from Ilsa Kuffner, Curt Storlazzi, Mike Field, Robert Spies, and two anonymous reviewers. Special thanks to USGS colleagues Charlene Tetlak, Mike Torresan, Tom Lorenson, and Jim Hein for assistance with sediment analyses; additional analysis was provided by SGS Minerals, Toronto. Use of trademark names or equipment does not imply USGS endorsement of products.

\section{References}

Anthony, K. R. N., and Hoegh-Guldberg, O. (2003). Kinetics of photoacclimation in corals. Oecologia, 134, 23-31.

Anthony, K. R. N., and Connolly, S. R. (2004). Environmental limits to growth: physiological niche boundaries of corals along turbidity-light gradients. Oecologia, 141, 373-384.

Bak, R. P. M., and Elgershuizen, J. H. B. (1976). Patterns of oil-sediment rejection in corals. Marine Biology, 37, 105-113.

Bastidas, C., Bone, D., and Garcia, E. M. (1999). Sedimentation rates and metal content of sediments in a Venezuelan coral reef. Marine Pollution Bulletin, 38, 16-24. 
Bothner, M. H., Reynolds, R. L., Casso, M. A., Storlazzi, C. D., and Field, M. E. (2006). Quantity, composition and source of sediment collected in sediment traps along the fringing coral reef off Molokai, Hawaii. Marine Pollution Bulletin, 52, 1034-1047.

Brown, E. K. (2004). Reef coral populations: spatial and temporal differences observed on six reefs off west Maui. Ph.D. thesis, University of Hawaii.

Calhoun, R. S., and Field, M. E. (2002). Beach and reef-flat sediments along the south shore of Molokai, Hawaii. In O.T. Magoon, L.L. Robbins, and L. Ewing (Eds.), Carbonate Beaches 2000, Proceedings of the First International Symposium on Carbonate Sand Beaches (pp. 163-171). Reston, Virginia: American Society of Civil Engineers.

Carver, R. E., 1971. (Ed.) Procedures in Sedimentary Petrology. New York: Wiley Interscience.

Dallmeyer, D. G., Porter, J. W., and Smith, G. J. (1982). Effects of particulate peat on the behavior and physiology of the Jamaican reef-building coral Montastraea annularis. Marine Biology, 68, 229-233.

Dollar, S.J., and Grigg, R.W. (2004). Anthropogenic and natural stresses on selected coral reefs in Hawaii: a multidecade synthesis of impact and recovery. Pacific Science, 58, 281-304.

Fabricius, K.E. (2005). Effects of terrestrial runoff on the ecology of corals and coral reefs: review and synthesis. Marine Pollution Bulletin, 50, 125-146.

Fabricius, K.E. and Wolanski, E. (2000). Rapid smothering of coral reef organisms by muddy marine snow. Estuarine, Coastal and Shelf Science, 50, 115-120.

Fitt, W. K., Brown, B. E., Warner, M. E., and Dunne, R. P. (2001). Coral bleaching: interpretation of thermal tolerance limits and thermal thresholds in tropical corals. Coral Reefs, 20, 51-65

Folk, R. L. (1974). Petrology of Sedimentary Rocks, Austin, TX: Hemphill Publishing.

Genty, B., Briantais, J. M., and Baker, N. R. (1989). The relationship between quantum yield of photosynthetic electron transport and quenching of chlorophyll fluorescence. Biochemica et Biophysica Acta, 990, 87-92.

Gilmour, J. P. (2002). Acute sedimentation causes size-specific mortality and asexual budding in the mushroom coral, Fungia fungites. Marine and Freshwater Research, 53, 805-812.

Glynn, P. W., Howard, L. S., Corcoran, E., and Freay, D. (1984). The occurrence and toxicity of herbicides in reef-building corals. Marine Pollution Bulletin, 15, 370-374.

Glynn, P. W., Szmant, A. M., Corcoran, E., and Cofer-Shabica, S. V. (1989). Condition of coral reef cnidarians from the Northern Florida reef tract: pesticides, heavy metals, and histopathological examination. Marine Pollution Bulletin, 20, 568-576.

Gulko, D., Maragos, J., Friedlander, A., Hunter, C., and Brainard, R. (2000). Status of coral reefs in the Hawaiian Archipelago. In Wilkionson, C. (Ed.), Status of coral reefs of the world: 2000, (pp. 219-238). Townsville: Australian Institute of Marine Science.

Guzman, H. M., and Jimenez, C. E. (1992). Contamination of coral reefs by heavy metals along the Caribbean coast of Central America (Costa Rica and Panama). Marine Pollution Bulletin, 24, 554-561. 
Harney, J. N., Grossman, E. E., Richmond, B. M., and Fletcher, C.H. III. (2000). Age and composition of carbonate shoreface sediments, Kailua Bay, Oahu, Hawaii. Coral Reefs, 19, 141-154.

Hodgson, G. (1989). The effects of sedimentation on Indo-Pacific reef corals. Ph.D. thesis, Univeristy of Hawaii.

Hodgson, G. (1990). Tetracycline reduces sedimentation damage to corals. Marine Biology, 104, 493-496.

Hoogenboom, M. O., Anthony, K. R. N., and Connolly, S. R. (2006). Energetic cost of photoinhibition in corals. Marine Ecology Progress Series, 313, 1-12.

Jokiel, P. L., Brown, E. K., Friedlander, A., Rodgers, S. K., and Smith, W.R. (2004). Hawaii Coral Reef Assessment and Monitoring Program: spatial patterns and temporal dynamics in reef coral communities. Pacific Science, 58, 159-174.

Jones, R. J., Hoegh-Guldberg, O., Larkum, A. W. D., and Schreiber, U. (1998). Temperature-induced bleaching of corals begins with impairment of the $\mathrm{CO} 2$ fixation mechanism in zooxanthellae. Plant Cell and Environment 21, 1219-1230.

Jones, R. J. and Kerswell, A. P. (2003). Phytotoxicity of Photosystem II (PSII) herbicides to coral. Marine Ecology Progress Series, 261, 149-159.

Jones, R. J., Muller, J., Haynes, D., and Schreiber, U. (2003). Effects of herbicides diuron and atrazine on corals of the Great Barrier Reef, Australia. Marine Ecology Progress Series, 251, 153-167.

Kohler, K. E. and Gill, S. M. (2006). Coral Point Count with Excel extensions (CPCe): A Visual Basic program for the determination of coral and substrate coverage using random point count methodology. Computers and Geosciences, 32, 1259-1269.

Lasker, H. R. (1980). Sediment rejection by reef corals: the roles of behavior and morphology in Montastrea cavernosa (Linnaeus). Journal of Experimental Marine Biology and Ecology, 47, 77-87.

Lombardi, M. R., Lesser, M. P., and Gorbunov, M. Y. (2000). Fast repetition rate (FFR) fluorometry: variability of chlorophyll a fluorescence yields of the corals, Montastrea faveolata (w.) and Diploria labyrinthiformes (h.) recovering from bleaching. Journal of Experimental Marine Biology and Ecology, 252, 75-84.

MacDonald, D. D., Carr, R. S., Calder, F. D., Long, E. R., and Ingersoll, C. G. (1996). Development and evaluation of sediment quality guidelines for Florida coastal waters. Ecotoxicology, 5, 253-278.

Marsh, J. A. (1970). Primary productivity of reef-building calcareous red algae. Ecology, 51, 255-263.

Ogston, A. S., Storlazzi, C. D., Field, M. E., Presto, M. K. (2004). Sediment resuspension and transport patterns on a fringing reef flat, Molokai, Hawaii. Coral Reefs, 23, 559-569.

Philipp, E., and Fabricius, K. (2003). Photophysiological stress in scleractinian corals in response to short-term sedimentation. Journal of Experimental Marine Biology and Ecology, 287, 57-78.

Piniak, G. A., and Brown, E. K. (2007). Growth and mortality of coral transplants (Pocillopora damicornis Linnaeus 1758) along a range of sediment influence in Maui, Hawai i. Pacific Science, in press 
Raberg, S., Nystrom, M., Eros, M., and Plantman, P. (2003). Impacts of the herbicides 2,4-D and diuron on the metabolism of the coral Porites cylindrica. Marine Environmental Research, 56, 503-514.

Ralph, P. J., Gademann, R., and Larkum, A. W. D. (2001). Zooxanthellae expelled from bleached corals at $33^{\circ} \mathrm{C}$ are photosynthetically competent. Marine Ecology Progress Series, 220, 163-168.

Ralph, P. J., Gademann, R., Larkum, A. W. D., and Kuhl, M. (2002). Spatial heterogeneity in active chlorophyll fluorescence and PSII activity of coral tissues. Marine Biology, 141, 639-646.

Rice, S. A. (1984). Effects of suspended sediment and burial upon survival and growth of Easter Gulf of Mexico corals. Mote Marine Laboratory Technical Report No. 87, Sarasota, Florida.

Riegl, B., and Branch, G. M. (1995). Effects of sediment on the energy budgets of four scleractinian (Bourne 1900) and five alcyonacean (Lamoruroux 1816) corals. Journal of Experimental Marine Biology and Ecology, 186, 259-275.

Rogers, C. S. (1983). Sublethal and lethal effects of sediments applied to common Caribbean reef corals in the field. Marine Pollution Bulletin, 14, 378-382.

Rogers, C. S. (1990). Responses of coral reefs and reef organisms to sedimentation. Marine Ecology Progress Series, 62, 185-202.

Saxby, T., Dennison, W. C., and Hoegh-Guldberg, O. (2003). Photosynthetic responses of the coral Montipora digitata to cold temperature stress. Marine Ecology Progress Series 248, 85-97.

SOEST. (2004). Coastal Intensive Site Network, Kanehoe Bay monitoring project. http://www.hawaii.edu/cisnet/contents.htm. Last accessed June 1, 2006.

Sokal, R. R., and Rohlf, F. J. (1995). Biometry. New York: W. H. Freeman.

SPSS. (1998). SYSTAT version 8.0.

Stafford-Smith, M. G., and Ormond, R. F. G. (1992). Sediment-rejection mechanisms of 42 species of Australian scleractinian corals. Australian Journal of Marine and Freshwater Research, 43, 683-705.

Stafford-Smith, M. G. (1993). Sediment-rejection efficiency of 22 species of Australian scleractinian corals. Marine Biology, 115, 229-243.

Storlazzi, C. D., Ogston, A. S., Bothner, M. H., Field, M. E., and Presto, M. K. (2004). Wave- and tidally-driven flow and sediment flux across a fringing coral reef: Southern Molokai, Hawaii. Continental Shelf Research, 24, 1397-1419.

Te, F. T. (2001). Responses of Hawaiian scleractinian corals to different levels of terrestrial and carbonate sediment. Ph.D. thesis, University of Hawaii.

Telesnicki, G. J., and Goldberg, W. M. (1995). Effects of turbidity on the photosynthesis and respiration of two south Florida reef coral species. Bulletin of Marine Science, 57, 527-539.

Theide, J., Chriss, T., Clauson, M., and Swift, S. A. (1976). Settling tubes for size analysis of fine and coarse fractions of oceanic sediment. Oregon State University School of Oceanography, Report 76-8. Corvallis, Oregon.

Thompson, J. H., and Bright, T. J. (1977). Effects of drill mud on sediment clearing rates of certain hermatypic corals. In P.L. Fore (Ed.), Proceedings of the 1977 Oil Spill Conference (pp. 495-498). Washington, DC: American Petrological Institute. 
Warner, M. E., Fitt, W. K., and Schmidt, G. W. (1999). Damage to photosystem II in symbiotic dinoflagellates: A determinant of coral bleaching. Proceedings of the National Academy of Sciences USA 96, 8007-8012.

Weber, M., Lott, C., and Fabricius, K.E. (2006). Sedimentation stress in a scleractinian coral exposed to terrestrial and marine sediments with contrasting physical, organic and geochemical properties. Journal of Experimental Marine Biology and Ecology, 336, 18-32.

Wesseling, I., Uychiaoco, A.J., Alino, P. M., Aurin, T., and Vermaat, J. E. (1999). Damage and recovery of four Philippine corals from short-term sediment burial. Marine Ecology Progress Series, 176, 11-15.

Wolanski, E., Fabricius, K., Spagnol, S., and Brinkman, R. (2005). Fine sediment budget on an innner-shelf coral-fringed island, Breat Barrier Reef of Australia.

Estuarine, Coastal and Shelf Science, 65, 153-158. 
Sediment and fluorescence yield

Fig. 1. Fluorescence yields $\left(\mathrm{F}_{\mathrm{v}} / \mathrm{F}_{\mathrm{m}}\right)$ for Montipora capitata and Porites lobata after shortterm sediment exposure. Error bars are standard deviations.

Fig.2. Fluorescence yields $\left(\mathrm{F}_{\mathrm{v}} / \mathrm{F}_{\mathrm{m}}\right)$ for Montipora capitata and Porites lobata as a function of the amount of sediment and duration of sediment stress.

Fig. 3. Fluorescence yields $\left(\mathrm{F}_{\mathrm{v}} / \mathrm{F}_{\mathrm{m}}\right)$ for Montipora capitata and Porites lobata as a function of sediment exposure. The dashed line indicates mud, and the solid line indicates sand.

Fig. 4. Recovery of fluorescence yield $\left(\mathrm{F}_{\mathrm{v}} / \mathrm{F}_{\mathrm{m}}\right)$ of Montipora capitata and Porites lobata after short-term sediment stress. Error bars omitted for clarity. Black and white bars at bottom of graph indicate ambient photoperiod.

Fig. 5. Tissue damage to a Montipora capitata fragment exposed to harbor mud for $45 \mathrm{~h}$. Each square in the plastic grid size is $1 \mathrm{~cm}^{2}$. 
Table 1

Grain size and bulk composition of sediment types applied to corals

\begin{tabular}{lll} 
& sand & mud \\
\hline$\%$ gravel $(>2 \mathrm{~mm})$ & 0.02 & 21.21 \\
$\%$ sand $(0.62-2 \mathrm{~mm})$ & 99.60 & 55.70 \\
$\%$ silt $(0.04-0.62 \mathrm{~mm})$ & 0.00 & 20.60 \\
$\%$ clay $(<0.04 \mathrm{~mm})$ & 0.38 & 2.48 \\
mean grain size $(\varphi)$ & 0.25 & 0.24 \\
sorting $(\varphi)$ & 1.18 & 2.43 \\
$\%$ carbonate & 83.2 & 36.7
\end{tabular}


Table 2

Chemical characteristics of sediment types applied to corals, compared with concentrations at other coral reef sites ( $\mathrm{a}=\mathrm{Guzman}$ and Jimenez, 1992; b = Bastidas et al., 1999; c = Bothner et al., 2006; d = Weber et al., 2006)

\begin{tabular}{|c|c|c|c|c|c|c|}
\hline & Sand & Mud & Costa Rica/Panama ${ }^{a}$ & Venezuela $^{\mathrm{b}}$ & Hawaii $^{\mathrm{c}}$ & Australia $^{\mathrm{d}}$ \\
\hline $\mathrm{CaO}$ & $44.6 \%$ & $21.7 \%$ & & & & \\
\hline $\mathrm{SiO} 2$ & $5.9 \%$ & $20.5 \%$ & & & & \\
\hline $\mathrm{MgO}$ & $5.5 \%$ & $2.6 \%$ & & & & \\
\hline $\mathrm{Al} 2 \mathrm{O} 3$ & $1.4 \%$ & $21.7 \%$ & & & & \\
\hline $\mathrm{Al}$ & & & 448-13476 ppm & $<0.001-2.57 \%$ & & $0.0018-0.30 \mu \mathrm{mol} \mathrm{g} \mathrm{DW}{ }^{-1}$ \\
\hline As & $7.5 \mathrm{ppm}$ & $12.9 \mathrm{ppm}$ & & & $12.0 \mathrm{ppm}$ & \\
\hline $\mathrm{Ba}$ & 18 ppm & $61 \mathrm{ppm}$ & & & & $0.016-1.62 \mu \mathrm{mol} \mathrm{g} \mathrm{DW}^{-1}$ \\
\hline $\mathrm{Cd}$ & $0.07 \mathrm{ppm}$ & $0.11 \mathrm{ppm}$ & $4.8-8.3 \mathrm{ppm}$ & $<0.2-12.5 \mathrm{ppm}$ & $0.053 \mathrm{ppm}$ & \\
\hline $\mathrm{Ce}$ & $9.21 \mathrm{ppm}$ & $33.5 \mathrm{ppm}$ & & & & \\
\hline $\mathrm{Co}$ & $12.3 \mathrm{ppm}$ & $26.6 \mathrm{ppm}$ & & & & \\
\hline $\mathrm{Cr}$ & 119 ppm & 334 ppm & 4.1-29.6 ppm & 4.9-86.5 ppm & $32.6 \mathrm{ppm}$ & \\
\hline $\mathrm{Cu}$ & $4.5 \mathrm{ppm}$ & $51.8 \mathrm{ppm}$ & 2.2-16.9 ppm & $1-40 \mathrm{ppm}$ & $10.4 \mathrm{ppm}$ & $0.051-0.32 \mu \mathrm{mol} \mathrm{g} \mathrm{DW}{ }^{-1}$ \\
\hline $\mathrm{Fe}$ & $1.69 \%$ & $8.52 \%$ & 237.3-11445 ppm & $0.4-2.8 \%$ & & $<0.001-0.069 \mu \mathrm{mol} \mathrm{g} \mathrm{DW}{ }^{-1}$ \\
\hline Hf & $0.5 \mathrm{ppm}$ & $4.32 \mathrm{ppm}$ & & & & \\
\hline $\mathrm{La}$ & $4.6 \mathrm{ppm}$ & $14.7 \mathrm{ppm}$ & & & & \\
\hline $\mathrm{Li}$ & $3 \mathrm{ppm}$ & $28 \mathrm{ppm}$ & & & & \\
\hline $\mathrm{Mn}$ & & & $17.1-525 \mathrm{ppm}$ & & & $0.11-7.97 \mu \mathrm{mol} \mathrm{g} \mathrm{DW}{ }^{-1}$ \\
\hline Mo & $0.18 \mathrm{ppm}$ & $0.72 \mathrm{ppm}$ & & & & \\
\hline $\mathrm{Nb}$ & 1.7 ppm & $14.1 \mathrm{ppm}$ & & & & \\
\hline $\mathrm{Ni}$ & $99.1 \mathrm{ppm}$ & $180.9 \mathrm{ppm}$ & 74-122.6 ppm & 0.8-111 ppm & $16.6 \mathrm{ppm}$ & $0.034-0.39 \mu \mathrm{mol} \mathrm{g} \mathrm{DW}^{-1}$ \\
\hline $\mathrm{P}$ & 504 ppm & 885 ppm & & & & \\
\hline $\mathrm{Pb}$ & $1.6 \mathrm{ppm}$ & $9.7 \mathrm{ppm}$ & 7.9-45.3 ppm & & $2.9 \mathrm{ppm}$ & $0.014-0.13 \mu \mathrm{mol} \mathrm{g} \mathrm{DW}{ }^{-1}$ \\
\hline $\mathrm{Rb}$ & $0.9 \mathrm{ppm}$ & $4.5 \mathrm{ppm}$ & & $<1-111$ ppm & & \\
\hline $\mathrm{Sc}$ & $6.4 \mathrm{ppm}$ & $21.9 \mathrm{ppm}$ & & & & \\
\hline $\mathrm{Sr}$ & $2976.5 \mathrm{ppm}$ & $1685.9 \mathrm{ppm}$ & & & & \\
\hline Th & $<0.2 \mathrm{ppm}$ & $1.2 \mathrm{ppm}$ & & & & \\
\hline $\mathrm{Ti}$ & $0.17 \%$ & $1.46 \%$ & & & & \\
\hline $\mathrm{U}$ & $1.4 \mathrm{ppm}$ & $1.3 \mathrm{ppm}$ & & & & \\
\hline $\mathrm{V}$ & $42 \mathrm{ppm}$ & $231 \mathrm{ppm}$ & 41-265.4 ppm & $5-42 \mathrm{ppm}$ & & $0.039-1.65 \mu \mathrm{mol} \mathrm{g} \mathrm{DW}{ }^{-1}$ \\
\hline $\mathrm{Y}$ & $9.8 \mathrm{ppm}$ & $15.2 \mathrm{ppm}$ & & & & \\
\hline
\end{tabular}


Sediment and fluorescence yield

0.04-1.14 $\mathrm{mol} \mathrm{g} \mathrm{DW}^{-1}$

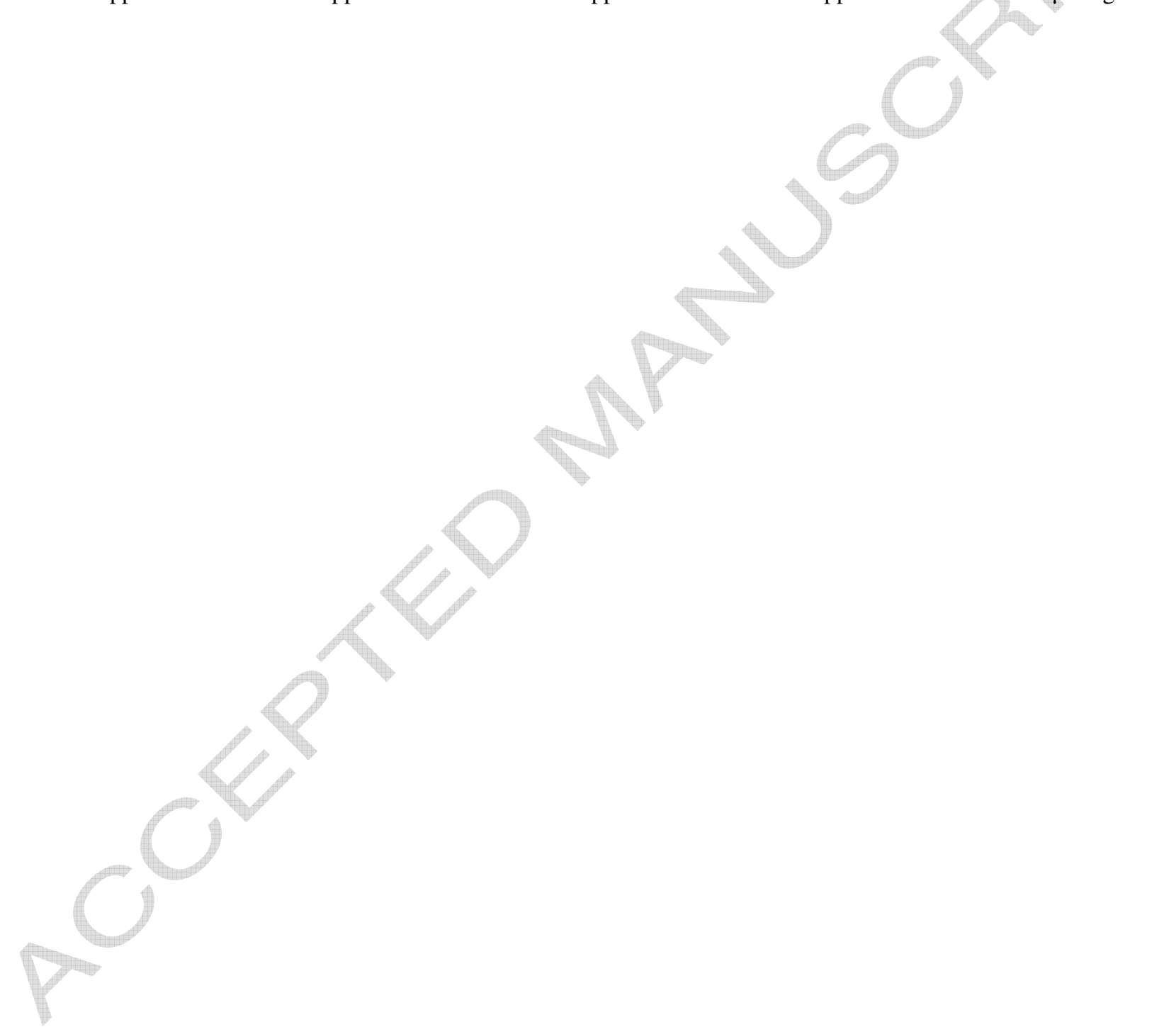


Table 3

Results of nonparametric two-way ANOVA (Scheirer-Ray-Hare extension of KruskalWallis; Sokal and Rohlf, 1995) for effects of sediment type and time on fluorescence yield of corals

\begin{tabular}{llllll}
\hline Species & effect & SS & df & SS/MS tot & P \\
\hline Montipora capitata & & & & & \\
\hline & sediment type & 1923.6 & 2 & 11.51 & $<0.001$ \\
& time & 2098.0 & 4 & 12.16 & $<0.001$ \\
& sediment*time & 1306.4 & 8 & 7.57 & $<0.01$ \\
& error & 2262.2 & 30 & & \\
\hline
\end{tabular}

Porites lobata

$\begin{array}{lllll}\text { sediment type } & 1841.7 & 2 & 10.68 & <0.005 \\ \text { time } & 2102.9 & 4 & 12.19 & <0.001 \\ \text { sediment*time } & 1501.4 & 8 & 8.70 & <0.005 \\ \text { error } & 2144.0 & 30 & & \end{array}$

Table 4

Results of nonparametric two-way ANOVA (Scheirer-Ray-Hare extension of KruskalWallis; Sokal and Rohlf, 1995) for effects of sediment type and time on fluorescence yield of corals, with control colonies omitted

\begin{tabular}{llllll}
\hline Species & effect & SS & df & SS/MS tot & P \\
\hline Montipora capitata & & & & & \\
\hline & sediment type & 0.667 & 1 & 0.013 & $<0.975$ \\
& time & 741.7 & 3 & 14.83 & $<0.005$ \\
& sediment*time & 59.0 & 3 & 1.18 & $<0.9$ \\
& error & 348.7 & 16 & & \\
\hline
\end{tabular}

Porites lobata

$\begin{array}{lllll}\text { sediment type } & 266.7 & 1 & 5.33 & <0.025 \\ \text { time } & 322.3 & 3 & 6.45 & <0.1 \\ \text { sediment*time } & 215.7 & 3 & 4.31 & <0.5 \\ \text { error } & 345.3 & 16 & & \end{array}$


Figure 1.
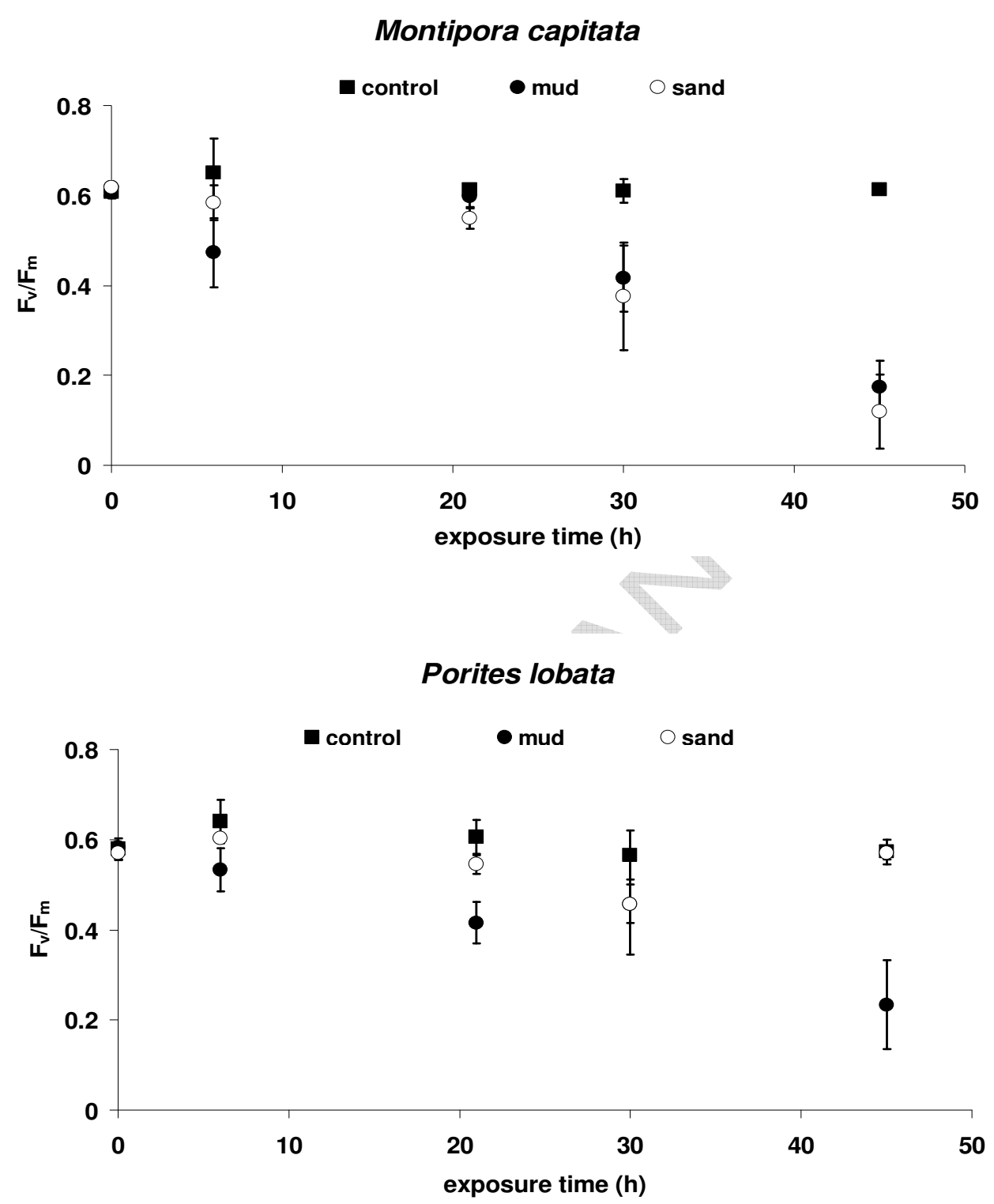
Figure 2.
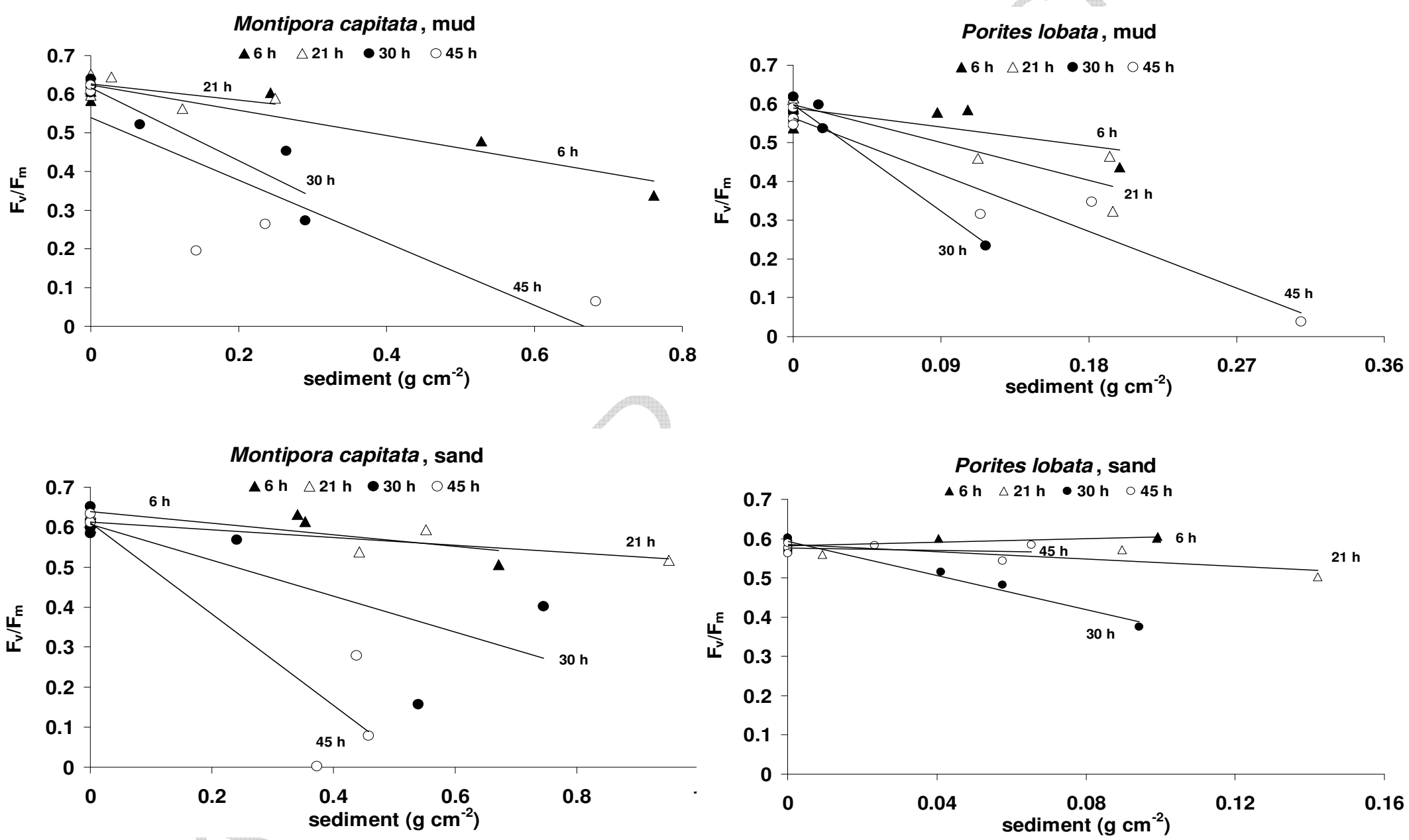
Figure 3.
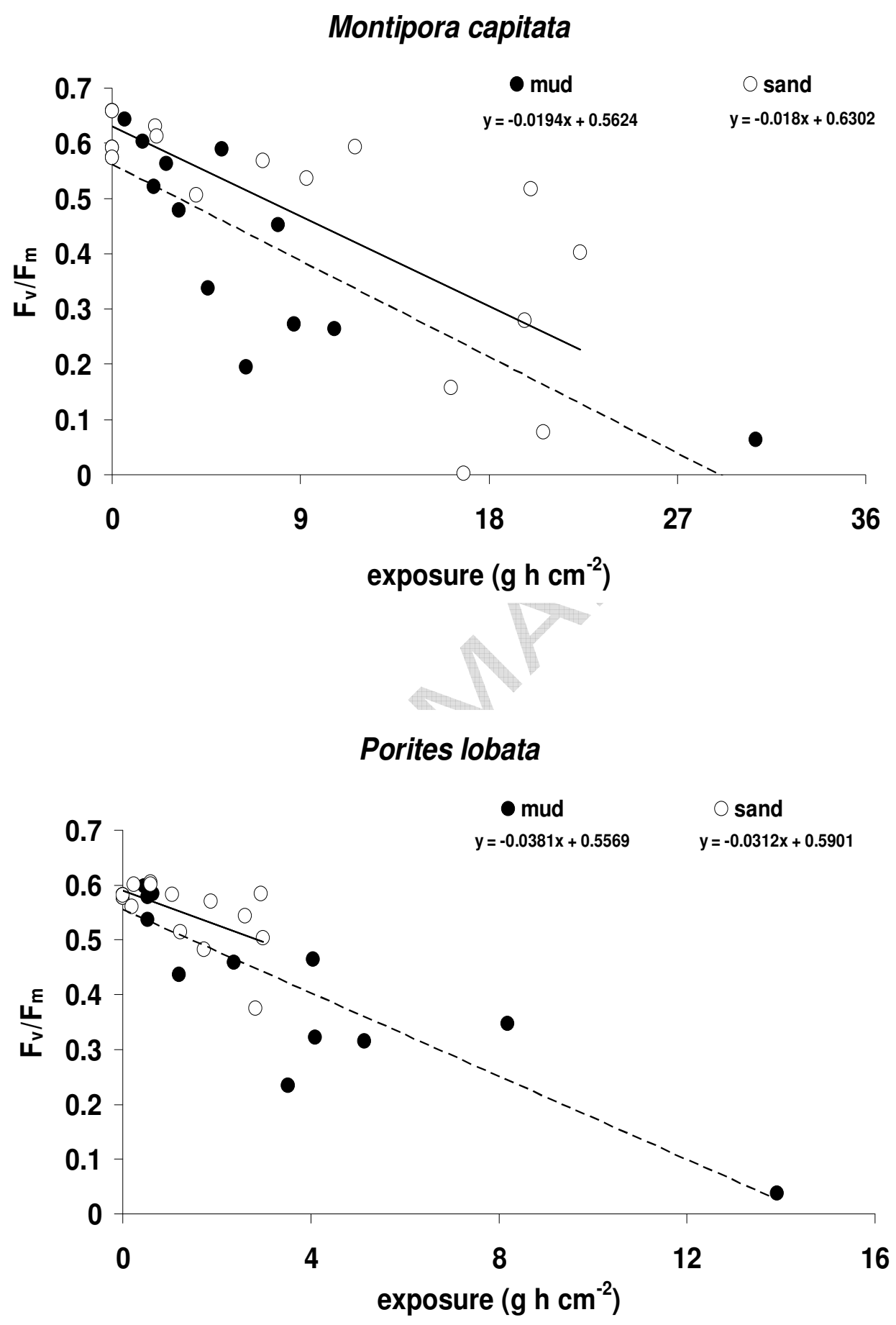
Figure 4.
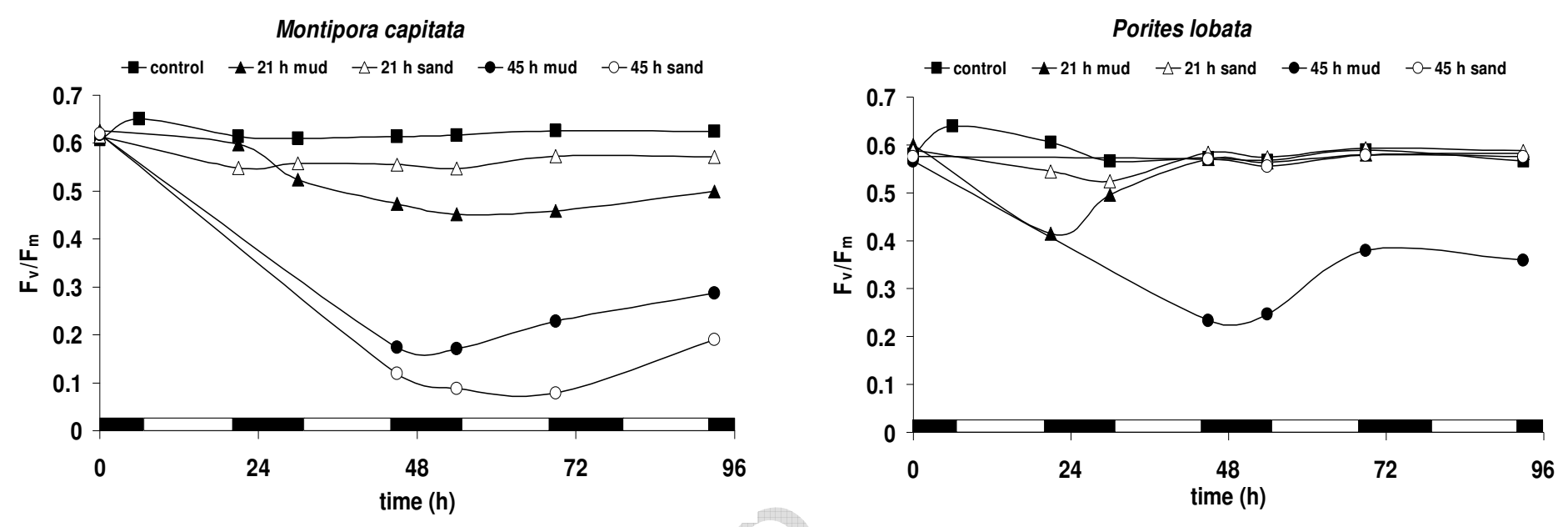
Figure 5.

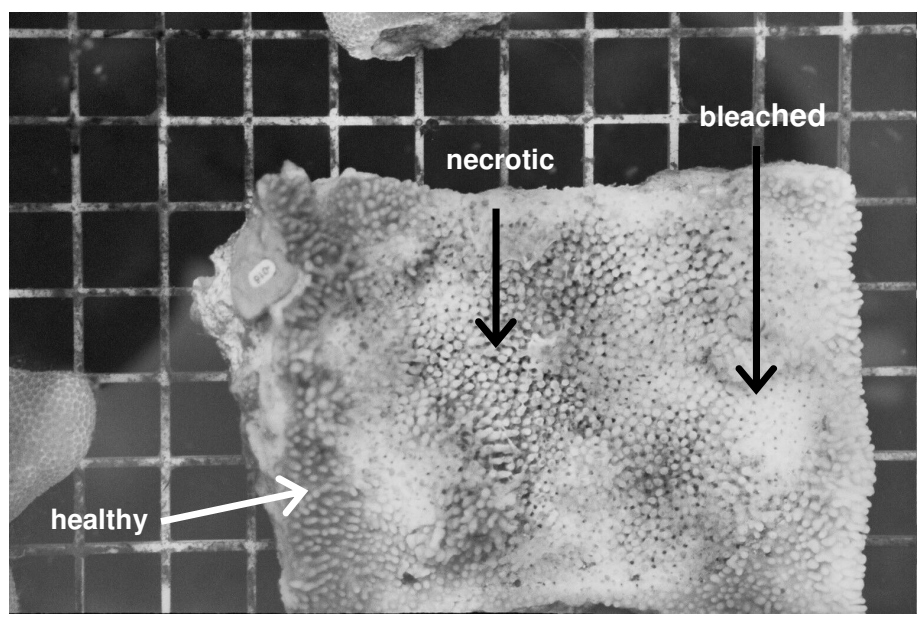

